\title{
INTERIORITY AND HUMAN EXPERIENCE: DOMINICUS DE FLANDRIA ON THE INTERIOR SENSES
}

\author{
La interioridad y la experiencia humana: \\ Los sentidos interiores en Domingo de Flandes \\ Brian García \\ $\mathrm{KU}$ Leuven (Belgium)
}

\begin{abstract}
This paper takes up the topic of the interior senses and sensible cognition as elaborated by Dominic of Flanders, a fifteenth-century Dominican thinker, in his short commentary, Expositio super libros De anima. At a time when Averroistic Aristotelianism was flourishing, and as nominalism spread across the Continent, Dominic's account of the soul and the interior senses demonstrates a commitment to Thomas Aquinas and, more broadly, scholastic realism. Dominic adopts the fourfold model of the internal senses advanced by Thomas. He carries forth Thomas's insistence that the sensus communis is both the root ( $\mathrm{ra}$ dix) and end (terminus) of sensitivity as such and the individual senses; he follows Thomas in privileging the cogitativa, and posits a more perfect form of memoria in man. Our study concludes by looking briefly at his Quaestiones in XII libros Metaphysica, where we find an innovative account of experimentum, which reveals the thought of a capable philosopher.
\end{abstract}

Key words: Internal senses, Cognition, Sensation, Aristotle, Thomas Aquinas, De Anima

\section{RESUMEN}

El objetivo del presente trabajo consiste en investigar el problema de los sentidos internos y del conocimiento sensible, tal y como es abordado por el pensador dominico del siglo XV Domingo de Flandes en su breve comentario Expositio super libros De Anima. En un momento de florecimiento del aristotelismo averroísta, y cuando el nominalismo se había extendido por todo el Continente, la doctrina de Domingo sobre el alma y los sentidos interiores demuestra su fidelidad a Tomás de Aquino y, de manera más amplia, al realismo escolástico - adoptando el modelo cuádruple de los sentidos interiores planteado por el Aquinate. Domingo acepta la insistencia de Tomás en que el sensus communis es tanto la raíz (radix) y el fin (terminus) de la sensibilidad y de los sentidos individuales. Domingo sigue a Tomás al privilegiar la cogitativa, y postula una forma más perfecta de la memoria en el hombre. Nuestro estudio concluye con una breve consideración sobre las Quaestiones in XII libros Metaphysica, donde nos encontramos con una presentación innovadora del experimentum, que revela el pensamiento de un filósofo muy competente.

Palabras clave: Sentidos internos, conocimiento, sensación, Aristóteles, Tomás de Aquino, De Anima.

\section{INTRODUCTION}

This paper takes up the topic of the interior senses as elaborated by Dominic of Flanders (ca. 1425-1479) in the relevant portions of his Expositio super libros De Anima. ${ }^{1}$ At a time

1 This work is alternatively given the title Brevis Recollecta, or Acutissimae Quaestiones super tres libros de Anima, written ante 1472. There are four surviving manuscripts: Berlin, Staatsbibl. Lat. qu. 946 (a. 1472 ), f. 
when Averroistic Aristotelianism was flourishing, and as nominalism spread across the Continent, Dominic's account of the soul and the interior senses demonstrates a commitment to Thomas Aquinas and, more broadly, scholastic realism. Dominic's concerns are not humanistic; his presentation is thus traditional, but accurate. Nonetheless, Dominic proves to be a capable thinker. Dominic of Flanders was a Dominican Master, originally from the presentday region near Lille, who spent his mature intellectual career working in Italy. ${ }^{2}$ After becoming a Master of Arts at Paris, where he studied with John Versoris $(\dagger 1482 / 1490)$, he entered the Dominican order at the convent of San Domenico in Bologna in 1461. There he taught philosophy and studied towards his Master of Theology with Peter of Bergamo (†1482). In 1470 he taught philosophy at the University of Florence, and then at Pisa (where the University had been transferred), from 1472 to 1474 . Dominic is best known for his massive commentary on Aristotle's Metaphysics (Quaestiones in XII libros Metaphysica, also called the Summa divinae philosophiae; hereafter, $Q M$ ), a work dedicated to Lorenzo de' Medici. ${ }^{3}$

Less well-known is a short commentary on Aristotle's De Anima. This work is essentially a summary of Thomas' own commentary on the text; however, Dominic at times incorporates treatments and material from Thomas's other works. While the ambit of modern thinkers-i.e., those scholastics working in the $14^{\text {th }}$ as well as the early $15^{\text {th }}$ centuries-taken up by Dominic

7ra_21 rb; Oxford, Bodl., Add. A. 370 (xv), f. 62-102v; Roma, Bibl. Univ. Alessandrina 246 (Xvi), f. 1-41; Torino, Bibl. Naz. H.IV.49 (xv), f. 86-135. Cf. Lapidge, M. et al., Compendium Auctorum Latinorum Medii Aevi (5001500), III.1: Conradus Mutianus Rufus-Dominicus de Pantaleonibus de Florentia magister, Firenze, SISMEL-Edizioni del Galluzzo, 2009, p. 109. The present author is preparing an edition of this text, based upon the manuscripts, as a part of a doctoral dissertation. For the purposes of this study, we will provide citations from the following edition, offering the book, treatise, chapter, and then folio and column: Divi Thomae Aquinatis in tres libros de Anima [...] Accedunt adhaec acustissime Quaestiones Magistri Dominici de Flandria [...], Venetiis: Hieronymum Scotum, 1550. This edition has been chosen out of convenience for the reader, since it is easy to acquire online and legible. This edition is available through some online resources, such as the SIEPM virtual library for Medieval Philosophy: <capricorn.bc.edu/siepm/books.html>. The earliest incunable (Venetiis 1496[?]) would have been ideal, however it lacks pagination; the changes introduced into this first edition are mostly carried over into the later editions. The Latin offered here in the footnotes has introduced some minor corrections to the text in light of the manuscripts, and does not respect the punctuation of this or any other edition.

2 The only two substantial analyses on Dominic to which we can refer are a lengthy article on Dominic's life and works by Ulrich Schikowski and a monograph by Léon Mahieu, published in 1940 and 1942, respectively: Schikowski, U., «Dominicus de Flandria O. P. (†1479) Seine Schriften, Seine Bedeutung», Archivum Fratrum Praedicatorum, 10 (1940), pp. 169-221; Mahieu, L., Dominique de Flandre (15e siècle): Sa Métaphysique, Paris: Vrin, 1942. These studies were written independently from each other, the publication date of the latter being delayed by the war. We must also mention Meersseman's short article: Meersseman, G., «Een Vlaamsch Wijsgeer: Dominicus van Vlaanderen», Thomistisch Tijdschrift voor Katholiek Kultuurleven, 1 (1930), pp. 385-400.

3 See Tavuzzi, M., Prierias: The Life and Works of Silvestro Mazzolini da Prierio, 1456-1527, Duke Monographs in Medieval and Renaissance Studies, 16, Durham/London, Duke University Press, 1997, p. 14; Kristeller, P. O., «Thomism and the Italian Thought of the Renaissance», in E. Mahoney (ed. \& trans.) Medieval Aspects of Renaissance Learning, Durham, Duke University Press, 1974, pp. 29-91, 49 [originally published as Le Thomisme et la pensée italienne de la Renaissance, Montreal, Institute d'Etudes Médiévales; Paris, Librairie J. Vrin, 1967]. Dominic's ideas concerning the proper subject of metaphysics - namely, that the object of metaphysics is being as it is divided into the ten categories (ens divisum per decem praedicamenta) - would find their way into the prominent Jesuit author Benedict Pereira's De communibus omnium rerum naturalium principiis et affectionibus; see Lohr, C. H., «Jesuit Aristotelianism and Sixteenth-Century Metaphysics», in Paradosis: Studies in Memory of Edwin A. Quain, New York, Fordham University Press, 1976, pp. 203-220, 209. It has further been suggested that Christian Wolff drew upon not only Francisco Suárez but also Dominic; see Ruello, F., «Christian Wolff et la scholastique», Traditio, 19 (1963), pp. 411-425. Martin Grabmann briefly notes that both Wolff and Suárez used Dominic's Metaphysics commentary; see Grabmann, M., Mittelalterliches Geistesleben: Abhandlungen zur Geshichte der Scholastik und Mystik, Band 1, München, Max Hueber, 1926, «Die Disputationes Metaphysicae des Franz Suarez in ihrer Methodischen Eigenart und Fortwirkung», p. 533. 
in this De Anima summary does not match the extensiveness of his Metaphysics commentary, he does argue explicitly against John of Jandun, and at times employs Giles of Rome as an authority. ${ }^{4}$ Dominic's Expositio super libros De Anima (hereafter, EDA) enjoyed a wide circulation, owing to its being appended to many printed editions of Thomas's own commentary on the work. ${ }^{5}$

In Dominic's division of the text, the divide between Books II and III of the De Anima occurs after the treatment of the proper, external senses, just before the elaboration of the common sense and phantasia (at 424b22). So, for Dominic, Book III begins precisely with the discussion which will lead to an account of the interior senses. ${ }^{6}$ Dominic includes here a brief note of the diverging opinions regarding the division of the text according to Giles, Albert the Great, and the 'modern' scholastics.?

Before we turn to the text, a word concerning the background of this conceptual framework is in order. The doctrine of the so-called internal senses is not present in Aristotle.

4 Dominic's citation of other authors is rather sparse; he explicitly names only Giles of Rome (6), Avicenna (4), Albert the Great (3), John of Jandun (2), Averroes (1), Boethius (1), and Radulphus Brito (1). The citation of Brito (ca. 1270-ca. 1320), occurring early on in the proemium, is indeed a very concise elaboration of Radulphi Britonis, Questiones super librum de anima, I.10: 'Utrum naturalis diffinit per materiam, logicus vero per formam'; the text at hand has recently been edited, in De Boer, S. W., «Radulphus Brito's Commentary on Aristotle's De anima», Vivarium, 50 (2012), pp. 245-354.

5 Of the twenty-two editions of Thomas' De Anima commentary printed between 1496-1660, seventeen included Dominic's EDA. See Gauthier, R.-A., «Préface», in Sancti Thomae de Aquino Opera Omnia, vol. 45,1: Sententia libri de Anima, Roma, Commissio Leonina, 1984), p. 19*-28*, 34*; see also Cranz, F. E., «The Publishing History of the Aristotle Commentaries of Thomas Aquinas», Traditio, 34 (1978), pp. 157-192, esp. 182-4. Beginning with the 1518 Venice edition, it was common that these editions include two concurrent translations of Aristotle's text-viz., the antiqua of Moerbeke as well as the nova by Argyropoulos - followed then by Dominic's summary. The Venice 1518 edition is notable insofar as it was prepared by Bartolomeo Spina, at the time when he had suspected that his fellow Dominican, Thomas de Vio Cajetan, had perverted Aquinas' teaching on the soul; see Gauthier, «Préface», p. 21*. There is no reason to believe that Dominic himself utilized the new translation by Argyropoulous, and he shows no concern to impose any changes to the key terminology in Thomas' traditional philosophical vocabulary.

6 Book III begins at the lemma, «Quod autem non sit sensus praeter quinque.» This lemma marks the location where we find William of Moerbeke's annotation, «Apud Grecos hic incipit tercius liber.» Throughout this paper, we will refer only to Dominic's division of the text as found in his Expositio.

7 Dominic claims that Book III begins here (at 424b22) according to Thomas, however, according to Giles and Albert, it does not begin until the next lectio (Dominic's following chapter, at 427a17); further, according to the modernos, Book III does not begin until the discussion concerning the possible and agent intellect (Dominic's third treatise, at the lemma, «De parte autem animae qua sapit et intelligit,» at 429a10). It must be stated that Dominic's elaboration, here at the beginning of Book III, is highly reminiscent of John Versoris' De Anima commentary: «Hic incipit tertius libri Aristotelis, quod hic incipit investigare distinctionem intellectus a sensu, et ut dicit Sanctus Thomas sic invenitur intitulatio apud grecos. Secundum autem Egidium de roma et Albertum liber tertius incipit ibi, Quoniam autem duabus differentiis, [...] sed secundum modernos liber tertius incipit ibi, De parte autem animae qua cognoscit. Sed ut dicit Egidium ista difficultas est modice utilitatis, ideo relinquenda est,» Versoris, J., De Anima, Lyon, 1489, lib. II, s.p., Q. 28: 'Utrum sint tamquam quinque sensus exteriores.' Regarding the conclusion of Book II, the printed editions include a brief discussion concerning its termination, while the manuscripts only make passing reference to the problem. Cf. EDA II, tr. 2, cap. 18, 77v, col. 2; the MSs. read: «Aer autem non patitur per sensationem, ideo non oportet quod habeat olfactum. Et sic terminatur secundus liber de anima secundum Doctorem Sanctum, secus autem secundum alios,» e.g., Oxford, Bodl., f. 92 ${ }^{\text {rb} ; ~ R o m a, ~}$ Aless., f. $30^{\mathrm{rb}}$. Gauthier has already indicated that the printed editions include not only a concordance of both Thomas' and Dominic's chapters prefacing each chapter, which is lacking in the manuscripts, but also some precise citations throughout which are neither found in the manuscripts; Gauthier wonders whether there is perhaps a second redaction made by Dominic, or rather whether the additional text that made its way into the editions was an intervention by the first publisher. This case found at the very end of EDA II is a good example of such a precise citation and related textual material which is not found in the manuscripts. 
That is, no general term exists in Aristotle's relevant works representing the collective sensitive powers which are posited besides the five proper, external senses. It cannot be doubted, however, that in both De Anima as well as De Memoria et Reminiscentia, Aristotle provides an account of the common sense, phantasia, and memory; there is also present in these works, at least in nascent form, a capacity or operation of the soul which will later be classified an estimative faculty-itself having some relation to phantasia. The internal senses posited as such appear only later in the Arabic, Hebrew, and Latin philosophical traditions. ${ }^{8}$ Discussion concerning the classification of the internal senses (and of their localization) continued through the medieval scholastic tradition, and well into the enduring Aristotelianism of the early modern period. A classic medieval enumeration of the interior senses - and a clear episode regarding the very debate-occurs in Thomas Aquinas's explicit reorganization of Avicenna's model. According to Thomas's account, Avicenna posits five interior senses: the common sense, phantasia, imagination, estimative power, and memory. ${ }^{9}$ (We here set aside the fact that Aquinas's classification of Avicenna's model is not entirely accurate.) Aquinas, however, finds a fifth power to be superfluous-i.e., one concerned with the composition and division of imagined forms, situated between estimation and imagination-and thus argues for a fourfold enumeration of the internal senses: the common sense, phantasia, the estimative power, and memory. ${ }^{10}$ Speaking generally, we can say that Thomas' teacher, Albert the Great, followed Avicenna's model, while Thomas is closer to Averroes's elaboration of the internal senses (insofar as a fifth faculty is rejectedThomas, however, rejects a compositive imaginative capacity, while Averroes rejects estimation as a specific faculty). Contemporaneously, Henry of Ghent posits a three-fold classification: sensus communis, memoria sensitiva, and phantasia ${ }^{11}$ Later, a thinker such as Francisco Suárez would, at the end of the $16^{\text {th }}$ century, take up the previous elaborationsand giving special attention to Aquinas and the Thomists-only to reduce the multiplicity of these sense powers to just one interior sense. ${ }^{12}$

8 The classic treatment of this matter remains Wolfson, H. A., «The Internal Senses in Latin, Arabic, and Hebrew Philosophic Texts», Harvard Theological Review, 28 (1935), pp. 69-133. More recently, one might refer to Black, D. L., «Imagination and Estimation: Arabic Paradigms and Western Transformation», Topoi, 19 (2000), pp. 59-75. Especially interesting, as it focuses specifically on the $14^{\text {th }}$ century, is Steneck, N. H., «The Problem of the Internal Senses in the Fourteenth Century», PhD diss., University of Wisconsin, 1970. A number of relevant contributions have been gathered together recently in Lagerlund, H. (ed.), Forming the Mind: Essays on the Internal Senses and the Mind/Body Problem from Avicenna to the Medical Enlightenment, Studies in the History of Philosophy of Mind, 5, Dordrecht, Springer, 2007; for a concise note, see Kärkkäinen, P., «Internal Senses», in H. Lagerlund (ed.), Encyclopedia of Medieval Philosophy: Philosophy Between 500 and 1500, Dordrecht: Springer, 2011, pp. 564-567. Covering a wide historical range, see the recent collection, Corcilius, K. \& D. Perler (eds.), Partitioning the Soul: Debates from Plato to Leibniz, Topoi: Berlin Studies of the Ancient World, 22, Berlin/ Boston, Walter de Gruyter, 2014.

9 «Sed contra est quod Avicenna, in suo libro de Anima, ponit quinque potentias sensitivas interiores, scilicet sensum communum, phantasiam, imaginativam, aestimativam, et memorativam,» ST Ia, 78,4, p. 255. All Latin text from the Summa theologiae is taken from the Leonine Edition: Opera Omnia, 5: Pars Prima Summae Theologiae, Romae ex Typographia Polyglotta, 1889, and page numbers refer to this volume. Text from Thomas' De Anima commentary is taken from: Opera omnia, vol. 45,1: Sententia libri De Anima, Roma: Commissio Leonina, 1984.

10 «t sic non est necesse ponere nisi quatuor vires interiores sensitivae partis: scilicet sensum communem et imaginationem, aestimativam et memorativam,»ST Ia, 78,4 c., p. 256.

11 See Brown, J. V., «Henry of Ghent on Internal Sensation», Journal of the History of Philosophy, 10 (1972), pp. 15-28.

12 See South, J. B., «Francisco Suárez on Imagination», Vivarium, 39 (2001), pp. 119-158. 


\section{THE COMMON SENSE}

The theme of the common sense arises only after each proper, external sense has been discussed. The whole of EDA III is divided into four treatises: the first takes up the common sense; the second looks at the distinction between sense and intellect; the third treats the intellective potency, in itself and of its parts (i.e., the possible and agent intellect); and the fourth discusses the motive potency. Our discussion now will focus upon the first treatise; it is in turn divided into three chapters. In the first chapter, Dominic advances two conclusions: (1) that one must not posit another proper sense besides the five already enumerated in Book II; and (2) that another proper sense must not be posited on account of the existence of common sensibles.

The argument supporting the first conclusion of the chapter is based upon the idea that 'perfect animals' have all of the senses, and do not have more than the five. The proof for the major premise is as follows:

For whatever has some sense-organ - through that organ some sensible objects are naturally ordered to be known-is able to know (cognoscere) every sensible object which is naturally known by that organ; this is clear, inductively, by looking at the case of a single sense-organ; but perfect animals have every sense organ, thus they know all sensible objects and consequently have all the sense capacities. From this it is clear that there are only five exterior and proper senses - viz., sight, hearing, smell, taste, and touch. ${ }^{13}$

Each sense-organ is able to grasp the entire range of sensible objects proper to it. It is interesting to note that Dominic explicitly emphasizes the threefold relation of organ, object, and power in his elaboration of the perfect animal: because the perfect animal has every organ of sense (organa sensus), it thus knows all sensible objects (sensibilia) and so has every sense capacity (sensus). ${ }^{14}$

A further elaboration is advanced in order to account satisfactorily for the fivefold enumeration of the external senses, depending on the passive nature of sensation and the kinds of impression involved in its process. Since the sensitive capacity is passive, i.e. naturally apt to be impressed by external sensible objects, Dominic determines that such an impression can occur in two ways: either the sense can be impressed according to a spiritual impression alone (which is proper to sight), or it can be impressed accompanied by both a spiritual and natural impression (and this is proper to the four remaining senses). This can further occur in two ways, viz., with the natural impression arising on the part of the object, or on the part of the organ. We can arrange the following schema:

sensus • secundum immutationem spiritualem tantum (visus)

- immutatione spirituali etiam naturali $\bullet$ ex parte obiecti • per motum localem (auditus)

- per alterationem (olfactus)

- ex parte organi - diffusum per totum corpus (tactus)

- in determinate parte corporis (gustus)

13 «Probatio maioris. Nam quicunque habet organum aliquod sensus, per quod nata sunt aliqua sensibilia cognosci, potest cognoscere omnia sensibilia, quae nata sunt cognosci per illud organum, ut patet inductive per singula organa sensus, sed animalia perfecta habent omnia organa sensus, ergo cognoscunt omnia sensibilia et per consequens habent omnes sensus [...]. Ex quo patet quod tantum sunt quinque sensus exteriores et proprii, videlicet visus, auditus, olfactus, gustus, et tactus,» EDA III, tr. 1, cap. 1, 78r, col. 1. The text omitted here is an intervention found in all the printed editions - and lacking in the manuscripts - which inserts Thomas' own text from his De Anima commentary into Dominic's summary (whose treatment already closely followed Thomas).

14 Dominic draws out what Thomas, in the relevant passage in his Commentary, leaves as implied-viz., that there is an underlying capacity within the sense-organ-saying only, «set animalia perfecta habent omnia organa sensus; ergo cognoscunt omnia sensibilia» (Sent. De Anima, lib. II, cap. xxv, p. 173). 
If the impression is emitted from the object, this can occur through a movement with respect to place (which is proper to hearing, since sound is transferred by a kind of locomotion) or through a medium by an alteration or transmutation (proper to smell); if the natural impression occurs on the part of the sense-organ, it will either be diffused throughout the whole body (as in the case of touch), or will occur in a determined part of the body (and this is proper to taste). Dominic's account of the distinction among the senses here offers but Thomas's own doctrine in succinct form..$^{15}$ Dominic here uses this elaboration, based upon the possible kinds of impression involved in sensation in order to show that there is no sense impression left unaccounted for, and hence no proper sense lacking.

It must now be shown that another proper sense ought not be posited on account of the existence of common sense-objects. Dominic indicates that he is advancing Aristotle's argument, appealing to the nature of per se sensation: whatever is known by one sense as its proper object is not known by another per se, but only incidentally (per accidens); the common sensibles-motion, shape, magnitude, etc.- are not known per se by any one sense, but by several; thus the common sense-objects are not proper objects of any one sense, and so we must not posit another proper sense on account of the common sensibles. The distinction between per se and per accidens sensation was taken up earlier in Book II. ${ }^{16}$

After Dominic has shown that the five external senses are properly enumerated, he needs to prove that the common sense must be posited distinct from those senses; he will do this explicitly in the third chapter. However, in the second chapter, certain doubts or difficulties must be addressed. These doubts arise from the Stagirite's elliptical remarks concerning sensation in De Anima III, 2. Dominic takes up the following: (1) whether sight perceives that it sees; (2) whether sense-objects and the sense power come into being and pass away together; and (3) why some sense-objects are destructive to the sense capacity, while others produce pleasure. These three arguments are common in the commentary tradition, drawing as they do from Aristotle's own discussion in the text at hand.${ }^{17}$ Regarding the first doubt, we draw attention to the response that contains an interesting characterization of the common sense. Dominic answers that one must say that sight, and any other particular sense, is able to be considered in two ways: in the first way, it can be considered properly (proprie) - in this way sight cannot by its action perceive its own vision; in the second way, vision can be considered in relation to the common sense-insofar as the very same impression impresses both the sight and the common sense, and it is in this way that sight can perceive its own vision, since the common sense itself distinguishes between the proper sense-objects of particular senses. Dominic elaborates upon this:

The reason for this is because, just as the center of a circle has a certain relation to the circumference and to the lines proceeding from the circumference to the center, so too does the common sense have a relation to the particular senses and to their acts. However, no line is able to tend towards the center of the circle, except that it goes

15 The individual proper senses were already taken up in detail in the second book, and the discussion concerning 'spiritual' and 'material' components of sensory impressions was treated in the immediately preceding chapter, at EDA II, tr. 2, ch. 18.

16 EDA II, tr. 2, cap. 7, 73v.

17 E.g., see-besides Thomas_John of Jandun: De Ianduno, I., Quaestiones super tres libros Aristotelis de Anima, Venetiis: Hieronumum Scotum, 1587 [reprint Frankfurt/Main, Unveränderter-Nachdruck, 1966], lib. II, QQ. 33 (an sensus particularis cognoscat suam propriam operationem), 34 (an sensibile in sensum agat), \& 35 (an excellens sensibile corrumpat sensum), s.p., cols. 203-209. These discussions match roughly with Aristotle's text at $425 \mathrm{~b} 12,425 \mathrm{~b} 26$, and $426 \mathrm{a} 28$, respectively. 
through the circumference, therefore no single sensation is able to reach the sensitive soul except with the mediation of the particular senses, and consequently the common sense does have particular sensations of the species of sense. ${ }^{18}$

Thomas himself does not employ such an analogy concerning the relation of the common and particular sense; the analogy of the centre point and circumference will again appear in the next chapter. In the context of the first doubt, Dominic eventually infers one conclusion in this chapter-viz., that it is necessary to posit the common sense over against the external senses.

The third chapter completes the treatment of the common sense. The first half supports the conclusion that the common sense must be posited for discerning among the various sense-objects. The argument runs thus: we perceive both the difference and the agreement among the various sense-objects insofar as they are sensible objects; but to know (cognoscere) sense-objects insofar as they are sense-objects pertains precisely to sense, thus to perceive the differences between various sensible objects - insofar as they are sensible-pertains to sense, but not to a particular sense; therefore perceiving the differences among various sense-objects belongs to the common sense. It is clear that the ability to discern among the various proper sense-objects does not belong to a particular external sense, since either it will pertain to one or several senses: it cannot belong to one external sense since that particular sense does not know (cognoscit) the difference among sensible objects (e.g., sight does not know colour and sound, properly); and it can neither belong to many senses, since it is the case that one man knows (cognoscit) the differences among diverse sense-objects, therefore it is due to one potency by which the various sensible objects are known.

The second half of this chapter argues that the common sense posits the difference among the various proper senses, while it itself knows and receives those sense-objects. This concluding portion of the first treatise is important, as we find again a particular example employed in order to elucidate the common sense, as well as a preliminary enumeration of the four internal senses as a conclusion to the first tractatus. The concise argument to prove the conclusion is as follows: for someone is able to posit the difference between two things only precisely by knowing those things, having perceived that they differ as well as their difference; but the common sense perceives the difference of various senses, therefore it follows that it simultaneously knows those various sense-objects. ${ }^{19}$ The argument arises that it is impossible for the same thing to be moved by various movers at the same time: since sense, in knowing its object, is moved (insofar as it undergoes a kind of passion), and since the various sense-objects are contraries, it must follow that it is impossible that the common sense knows the various sense-objects at the same time as positing the difference between them. According to Dominic, Aristotle is not content simply to concede that what is the same in subject, yet various at the level of conceptual abstraction, is able to be moved by contrary motions. Rather, what is the same in subject, yet diverse in concept, is able to be moved by contrary motions only potentially, but never in act. He continues:

18 «Cuius ratio est, quia sicut se habet centrum circuli ad circunferentiam et ad lineas procedentes a circunferentia ad centrum, ita se habet sensus communis ad sensus particulares et ad actionis eorundum: sed nulla linea potest pertingere ad centrum, nisi transeat per circumferentiam, ergo nulla sensatio potest pertingere ad sensationem nisi mediantibus sensibilibus particularibus, et per consequens sensus communis habet particulares sensationes specierum sensuum,» EDA III, tr. 1, cap. 2, 78v, col. 1.

19 «Nam nullus potest ponere differentiam inter aliqua, nisi cognoscat illa, quae differunt dum eorum differentiam percipi, sed sensus communis percipit differentiam diversorum sensuum, ut patet per praecedentem conclusionem, ergo sequitur quod simul cognoscit illa diversa sensibilia,» EDA III, tr. 1, cap. 3, 79r, col. 1. 
Thus it must be said that, according to the Philosopher, the common sense is like a point, which is a center of a circle, and such a point is considered both as one and as two: it is considered as one, insofar as from it all lines proceed to the circumference; it is considered as two, however, insofar as it is the beginning of one line and the end of another. Similarly the common sense can be considered both as one or two: it is one considered as it is the root of all the exterior senses, insofar as the sensitive powers proceed from the common sense to the exterior organs; it is considered as two, insofar as it is affected by the various impressions of the exterior senses. Hence it is not unfitting that the common sense be moved simultaneously by contrary motions insofar as it is the principle and terminus of the above-stated impressions. ${ }^{20}$

The discussion here stems from Aristotle's curious remarks at 427a10-14, which concludes De Anima III, 2. In taking up the problem of whether a single thing can be moved at one and the same time by contrary motions, Aristotle indeed answers that it can only be so potentially. Aristotle offers the following example:

Just as what is called a point is, as being at once one and two, properly said to be divisible, so here, that which discriminates is qua undivided one, and active in a single moment of time, while qua divisible it twice over uses the same dot at one and the same time. So far then as it takes the two as limit, it discriminates two separate objects with what in a sense is separated; while so far as it takes it as one, it does so with what is one and occupies in its activity a single moment of time..$^{21}$

In trying to elucidate the passage, Thomas offers instead a simile of a point between two ends of a line, which can be regarded either as 'one' or 'two'-either by continuing the parts of the line and so having a common end, or by taking the point to be both the end of one line and the beginning of another. Employing this model, Thomas is able to conclude: the sensitive capacity is diffused into the organs of the five senses from a kind of common root (radix communis), from which the sensing power proceeds to every organ, and also to which all impressions of each particular organ are terminated. This, then, can be considered in two ways: (1) as one principle and one terminus of all sensible impressions; and (2) as the principle and end of this or that particular sense. ${ }^{22}$ Prima facie, it seems that Dominic's elaboration here of the common sense is closer to that of Averroes than that of Aquinas. Dominic indeed maintains Thomas's conception of the common sense as both root (radix) and end (terminus) of

20 «Ideo aliter dicendum est secundum Philosophum quod sensus communis se habet ut punctus, qui est centrum circuli, qui quidem punctus consideratur ut unum, et ut duo. Ut unum, inquantum ab eo procedunt omnes lineae ad circunferentiam, ut duo vero inquantum est principium unius lineae et finis alterius. Similiter sensus communis consideratur ut unus et duo. Unus, inquantum est radix omnium sensuum exteriorum, inquantum a sensu communi procedunt virtutes sensitivae ad organa exteriora. Et consideratur ut duo, inquantum immutat secundum diversas immutationes sensuum exteriorum, unde non est inconveniens quod moveatur simul motibus contrariis inquantum est principium <et terminus> immutationum praedictarum,» EDA III, tr. 1, cap. 3, 79r, col. 1.

21 Trans. Smith, J. A., in J. Barnes (ed.), Complete Works, vol. 1, Princeton, Princeton University Press, 1991, p. 48. The text Dominic would have drawn from, of course, is that of Moerebeke: «Set sicut quod vocant quidam punctum aut unum aut duo, sic et divisibile. Secundum quod quidem igitur indivisible, unum discernens est et simul; secundum vero quod divisibile, bis utitur eodem signo simul; in quantum quidem igitur pro duobus utitur termino, duo iudicat et separata sunt, ut in separato; in quantum vero unum, uno et simul,» in Sent. De Anima, lib. II, cap. XXVII, p. 182.

22 «sic intelligendum est quod vis senciendi diffunditur in organa quinque sensuum ab aliqua una radice communi a qua quidem procedit vis senciendi in omnia organa et ad quam terminantur omnes inmutationes singulorum organorum; potest ergo considerari dupliciter: uno modo prout est unum principium et unus terminus omnium sensibilium inmutationum, alio modo prout est principium et terminus huius et illius sensus, Sent. De Anima, lib. II, cap. XXVII, p. 185. 
sensitivity and the individual sense powers. However, Dominic must not have found Thomas' analogy of the point that makes two segments of a line altogether convincing, and here instead follows other authors in the commentary tradition in discussing instead the example of the centre of a circle-such as Themistius, Averroes, Peter of Spain, Albert the Great, and Adam of Buckfield. ${ }^{23}$ A safe wager could be made that Dominic's more proximate sources were John of Jandun ${ }^{24}$ and John Versoris. ${ }^{25}$

After the analogy of the circle, its point and circumference, a doubt arises which surmises that the exterior sense is more perfect that the common sense. To respond to this doubt-that the exterior sense is more noble, seeing as it acts as a mover for the common sense, the mover being more noble and excellent (nobilius et praestantius) - Dominic again employs the conception of common sense as the root of sensitivity: the common sense is absolutely more perfect, first since it receives sensible species in an immaterial way, and secondly since it is the root and foundational principle of every exterior sense; however, the exterior sense is said to be more perfect in a qualified way, insofar as it moves the common sense; however, the common sense for Aristotle, according to Dominic, is more perfect in an absolute consideration (simpliciter).

The second doubt that arises will give way to a first complete account of the internal senses; it is doubted whether besides the common sense and the exterior senses any other internal sense ought to be posited. Dominic's decision to include such a discussion departs from Thomas; in the relevant lectio, Thomas offers no such schematic account of the internal senses in his Commentary. As it turns out, Dominic is following the order of topics presented by John Versoris in his commentary; in fact, the two objections listed by Dominic are the first two of four posed by Versoris (very nearly verbatim). ${ }^{26}$ Dominic's specific responses to these objections are also adapted from Versoris. ${ }^{27}$ What is important to note here is that Dominic

23 See Sent. De Anima, p. 185, note line 165. This discussion-pertaining precisely to the ancient commentators-is taken up in some detail in De Corte, M., «Notes exégetiques sur la théorie Aristotélicienne du sensus communis», The New Scholasticism, 6 (1932), pp. 187-214.

24 Cf. de Ianduno, I., Quaestiones super tres libros Aristotelis de Anima, lib. II, Q. 36, s.p., col. 211: «Et quia istud fuit difficile intelligere, ideo Aristotles induxit sermonem in via exempli, ut dicit Commentator, videmus enim quod punctus in medio circuli existens est unus secundum se, et tamen secundum quod est terminus alterius et alterius lineae ductae ab ipso ad circunferentiam diversificatur, aliud enim est ipsum esse terminum huius lineae, et aliud est ipsum esse terminum alterius. Proportionabiliter autem est in proposito. Nam ille sensus communis est una virtus secundum suam essentiam, sed differt secundum diversa esse, quae recipit a diversis sensibilibus, quorum immutationes perveniunt ad ipsum, et secundum quod est alius et alius cognoscit illa diversa sensibilia, ut per formam albi cognoscit album, et per formam dulcis dulce [...].»

25 We prefer the surname 'Versoris' to that of 'Versor,' despite the fact that the latter is largely asserted in the secondary literature. Cf. Versoris, J. De Anima, Köln, 1496, lib. II, s.p.: «Utrum sensus particulares percipiant suas actiones. [...] Sensus communis potest percipere actiones sensuum particularium, patet quia sicut se habet centrum circuli ad cirunferentiam, ita sensus communis ad sensus particulares. Sed nihil potest moveri ad centrum circuli ab extra nisi transuendo circunferentiam eius. Ergo nullum sensibile pervenit ad sensum communem nisi mediante sensu particulari qui mediat inter sensibile et sensum communem, ergo sicut sensus exterior reducitur ad actum per suum obiectum imutans ipsum, ita sensus communis fit in actu per sensum particularem actuatum per proximum sensible eius. Ergo sensus communis habet iudicare de actionibus sensuum particularium.»

26 Cf. Versoris, De Anima, lib. II, s.p.: «Utrum praeter quinque sensus exteriores in animalibus perfectis sunt quinque sensus interiores, scilicet sensus communis, imaginativa, fantasia, estimativa, et memoria. Arguitur quod non, quia commune non distinguitur contra proprium, ergo sensus communis non debet enumerari inter potentias sensitivas praeter sensus exteriores. Secundo. Fantastiatum et memoratum sunt passiones primi sensitivi, scilicet sensus communis, sed passio non distinguitur contra suum subiectum, ergo fantasia et memoria non distinguitur a sensu communi.»

27 «Ad primum dicendum quod licet commune per praedicationem non distinguatur contra proprium, commune tamen per cognoscibilitatem et causalitatem distinguitur contra proprium, ut in proposito. Ad secun- 
offers a presentation of the internal senses that accurately follows Thomas' fourfold model. ${ }^{28}$ We can arrange the following schema:

sensus $\bullet$ perceptivus specierum sensatarum • ordinatur ad accipiendum illas species (sensus communis)

- ad retinendum et conservandum eas (imaginativa)

- perceptivus intentionum

- ordinatur ad recipiendum illas intentiones (aestimativa)

- ad retinendum et conservandum illas intentiones (memoria)

The concise and systematic elaboration is of course reminiscent the classic treatment in the Summa theologiae. ${ }^{29}$

\section{PHANTASIA AND MEMORY}

Dominic's second treatise takes up De Anima III, 3, and is divided in turn into three chapters. The first chapter advances two conclusions: (1) that perceiving (sapere) and understanding (intelligere) are not the same as sensing (sentire); and (2) that phantasia is not the same as opinion. Dominic first shows that sensing is not the same as perceiving (for sapere, in the sense of 'cognition' and not indicative of intellectual understanding) since, while sensation belongs to all animals, perception belongs only to a restricted group. Next, Dominic shows that sensation is not the same as understanding (intelligere) on the grounds that the true and false belong to understanding but not to sensation, and that understanding belongs only to rational creatures. Regarding the impossibility of deception concerning the per se objects of sense, Dominic answers the fourth objection by specifying the first and second operations of the intellect-the first is not deceived concerning its proper intelligible object, though the second operation of the intellect is able to err in its process of separation and composition (dividendo vel componendo). The second conclusion is proved insofar as opinion follows from understanding, while phantasia follows from sense; understanding and sense are clearly distinct, so opinion and phantasia cannot be the same. Secondly, the ability to imagine (phan-

dum dicendum quod memoria et phantasia dicuntur passiones primi sensitivi non tanquam subiecti, sed tanquam causae, inquantum una potentia fluit ab anima mediante alia, ut supra declaratum est,» EDA III, tr. 1, cap. 3,79 r, col. 2 .

28 «Dicendum quod praeter sensus exteriores ponuntur quatuor sensus interiores, qui sunt sensus communis, vis imaginativa, quae dicitur phantasia in brutis, et aestimativa, quae dicitur vis cogitativa, aut ratio particularis in homine, et memoria. Quorum sic potest formari sufficientia. Nam sensus est perceptivus sensibilium, aut ergo est perceptivus specierum sensatarum aut intentionum quae non percipiuntur a sensu exteriori. Si primum, hoc est dupliciter, vel talis sensus ordinatur ad recipiendum illas species, et sic est sensus communis, vel ad retinendum et conservandum, et sic est vis imaginativa, quae dicitur thesaurus specierum sensatarum. Si secundum, hoc est dupliciter, vel ordinatur ad recipiendum illas intentiones, et sic est aestimativa in brutis, et cogitativa sive ratio particularis in hominibus, vel ordinatur ad retinendum et conservandum illas intentiones, et sic est sensitiva memoria. Et licet recipere et retinere in spiritualibus non pertineant ad diversas potentias, tamen in corporalibus ad aliquam potentiam pertinet recipere, et ad aliam retinere. Videmus enim quod illae quae bene recipiunt male retinent, et illae quae male recipiunt bene retinent,» EDA III, tr. 1, cap. 3, 79r, cols. 1-2.

29 Cf. $S T, I a, 78,4$, c., p. 256 . The entirey of the corpus is with much more detail, beginning with an account why one power cannot both receive and retain, and then a more elaborate account of the estimative power. The corpus then looks at the cogitative power in man, and then explicitly responds to Avicenna's model of the internal senses. Cf. Versoris, De Anima, lib. II, s.p. «Conclusio praeter quinque sensus exteriores in animalibus perfectis sunt alii quatuor sensus interiores, scilicet sensus communis, imaginativa sive fantasia, estimativa et memoria, patet satis ex dictis. Veruntamen Avicenna ponit quinque interiores potentias quia distinguit imaginativam a fantasia, sed Thomas non ponit realem differentiam inter ipsos quia operatio imaginative et fantasie possunt eidem convenire.» 
tasticare) is in our power, while holding an opinion is not wholly in our power insofar as some reason or conviction is required by which we opine correctly or falsely. The objection and response that follows from this concerns the necessity of the working of the imagination in the holding of any opinion (non possumus opinari nisi phantasticando): Dominic responds, affirming the necessity of phantasia, indicating that, while it is true that we are not able to form opinions without the mediation of phantasia, it does not follow that opinion and phantasia are the same.

Once the considerations of phantasia by way of negation have been completed, the next chapter then draws to a conclusion concerning the place of phantasia among the other cognitive powers, and posits three conclusions and one corollary. Within the context of the first conclusion - that phantasia is not simply sensation in potency-we find a distinction between determinate and indeterminate phantasia: «[...] phantasia is twofold: the first kind is indeterminate and imperfect, and such a kind belongs well to all animals, which here does not pertain to the matter at hand; the other is a determinate phantasia, which has a determinate organ, and such a kind does not belong to all animals». ${ }^{30}$ This brief attribution of the determinate phantasia to a particular organ is notable, but that is all Dominic says at this point. The division between determinate and indeterminate phantasia had indeed already occurred in Book II. In the last chapter of the first tractatus of Book II-taking up the relation among the vegetative, sensitive, motive, and appetitive parts of the soul-an objection arose that claimed phantasia to be an organic power situated in a specific part of the body; Dominic responds in a similar vein, employing the twofold distinction of phantasia, remarking that the indeterminate and imperfect phantasia is not found in a determinate part of the body, while the determinate phantasia (found only in the perfect animals) does require a specific part of the body. ${ }^{31}$ The theme of phantasia will of course also return in the later chapters of EDA III, wherein the relation between appetitus and phantasia is discussed. Dominic there recalls the distinction between indeterminate and determinate phantasia, and then makes a further division of the latter into phantasia sensibilis and phantasia rationalis. ${ }^{32}$ Let us for a moment, however, depart from the text at hand and refer to a separate work of Dominic's in order to find a more synthetic treatment of this very topic.

Within the first book of his Metaphysics commentary, we find an article that takes up the question, «utrum omnia animalia habeant memoriam.» The first objection answering in the affirmative posits that memory follows from phantasia, and phantasia follows from sensation; since all animals have imagination or phantasia, all animals thus have memory. Dominic responds that phantasia is twofold, determinate and indeterminate: memory follows only from determinate phantasia, which has a specific organ in the subject and is found only in the

30 «t si dicatur contra cuicunque inest sensus, eidem inest phantasia, ut supra in secundo concessum est, ergo sicut sensus competit omnibus animalibus, ita et phantasia. Dicendum quod duplex est phantasia, quaedam est indeterminata et imperfecta, et talis bene competit omnibus animalibus, de qua non est hic ad propositum. Alia est phantasia determinata quae habet determinatum organum, et talis non inest omnibus animalibus,»EDA III, tr. 2, cap 2, 79v, col. 1 .

31 «Ad secundum dicendum quod duplex est phantasia: quaedam est indeterminata et imperfecta, et talis non habet determinatam partem, de qua hic est sermo, alia est phantasia determinata, quae repiritur in animalibus quibusdam perfectis, et talis requirit determinantem partem, de qua procedebat argumentatio,»EDA II, tr. 1, cap. 4, 69r, col. 1 .

32 See EDA III, tr. 4, cap. 2, 83r-83v: «Alia est phantasia determinata, et talis est duplex. Quaedam est sensibilis, quae fit absque deliberatione, et talis invenitur in animalibus utique perfectis, quae etiam ratio non dicitur. Alia est phantasia rationalis, quae videlicet habet fieri cum quadam deliberatione et discursu, et talis reperitur in hominibus.» 
perfect animals having all of the senses; such a kind of phantasia is able to apprehend things removed from the sensibly present. Indeterminate phantasia however can only apprehend things in the sensibly present, and cannot imagine something removed from the here and now-such a confused phantasia is found in the imperfect animals, and memory does not follow from it. Dominic further specifies that indeterminate phantasia and the sense of touch in the lower animals are distinct only at a conceptual level (solum ratione), since in an absolute consideration what the indeterminate phantasia apprehends falls under the realm of touch, while what is apprehended as agreeable or unpleasant are said of phantasia. ${ }^{33}$ It must be noted that this account of the imperfect phantasia touches briefly upon content which broaches the powers typically attributed to the estimativa (e.g., the perception of nocivus or conveniens), which we will take up shortly.

Dominic elaborates upon a twofold memoria in the same article. The fourth objection argues that no animal lacking reason will have memory, since reminiscence is an affection of memory, yet brute animals are without reminiscence. Dominic responds that memory is twofold, perfect and imperfect: perfect memory is that of rational creatures whose property is reminiscence, which presupposes comparison and discursive operation; imperfect memory belongs to brute animals, which presupposes only a natural kind of instinct, and not reminiscence proper. The process of comparison (collatio) however, should be carefully noted to be twofold: on the one hand, it is discursive, moving from the more to the less known, which pertains to the memory belonging to man properly; on the other, comparison is taken in itself, which does not involve discursive reasoning but rather follows only from natural instinct-in this way it is fitting to posit some form of memory to brutes. ${ }^{34}$ Recalling the definition of memoria sensitiva given at the end of the first tractatus of EDA III, we emphasize here that the proper function attributed to the memory qua internal sense power follows Thomas's elaboration in the Summa ${ }^{35}$ so far as Dominic determines the memory as ordinatur ad retinendum et conservandum illas intentiones-viz., those intentiones of the estimative or cogitative power.

33 «[...] duplex est phantasia, videlicet determinata et indeterminata. Phantasia enim determinata est quae determinate apprehendit hoc, vel illud in hoc tempore, vel in illo: talis autem solum reperitur in animalibus perfectis, quae habent omnes sensus: talis etiam habet determinatum organum, in subiecto, et ad hanc solum, sequitur memoria. Sed phantasia indeterminata, est quae nihil apprehendit nisi in praesentia sensibilis, nec imaginatur aliquod distans: et talis phantasia inest animalibus imperfectis, quae solum quadam imaginatione confusa imaginantur aliquid, vel ut nocivum, et sic retrahuntur, vel ut conveniens, et sic dilatantur, et se diffundunt super illud. Ad talem autem imaginationem, seu phantasiam non sequitur memoria. Et si quaeratur, utrum talis phantasia imperfecta, et tactus, in animalibus imperfectis different realiter. Dicendum, quod differunt solum ratione: quia inquantum ille sensus, aliquid apprehendit simpliciter et absolute, tunc dicitur tactus. Sed inquantum apprehendit idem, sub ratione convenientis, vel disconvenientis, tunc dicitur phantasia.» De Flandria, D., In duodecim libros Metaphysicae Aristotelis Quaestiones, Köln, 1621 [reprint Hildesheim, Georg Olms, 2010], hereafter QM I, Q. 3, a. 3 , p. 22 , col. $1 \mathrm{~B}$.

34 «Ad quartum dicendum, quod duplex est memoria. Quaedam est perfecta, cuius proprietas est reminiscentia, et talis est memoria creaturae rationalis, quae non reperitur in brutis. Alia est memoria imperfecta, ad quam non sequitur reminiscentia, et talis bene reperitur in brutis: prima quidem praesupponit collationem et discursum, secunda vero non, sed solum instinctum naturalem. Est tamen sciendum, quod collatio est duplex. Quaedam est discursiva, qua proceditur de magis noto ad minus notum, et haec, tantum est in homine, quae pertinet ad memoriam proprie dictam, cuius proprietas est reminisci. Alia est collatio in proprie dicta, quae non est discursiva secundum rationem, sed solum ex instinctu naturae, et talem inveniri in brutis non est inconveniens.» $Q M$ I, Q. 3, a. 3, p. 22, col. 1C.

35 Cf. $S T I a, 78,4$, c., p. 256: «Ad apprehendenum autem intentiones quae per sensum non accipiuntur, ordinatur vis aestimativa. Ad conservandum autem eas, vis memoriativa, quae est thesaurus quidam huiusmodi intentionum.» 
Returning to the second treatise of EDA, the second chapter goes on to argue that phantasia is neither understanding nor science, that phantasia is not opinion, and then infers that phantasia can neither be some composite made of up sensation and opinion. The final short chapter affirms Aristotle's well-known definition concerning phantasia: phantasia est quidam motus factus a sensu secundum actum. We here draw attention to one of the final points of this treatise: Dominic indicates that, according to Aristotle, phantasia sometimes is concerned with what is false. The reason for this is that, while sensation is deceived concerning the per se sensibles in very few instances, concerning the incidental objects of sense (per accidens) sensation errs often, and even more so concerning the common sensibles; thus a fortiori phantasia is deceived concerning phantasms, since phantasia withdraws farther from the root of the cognitive power. The point we should notice is the arrangement between phantasia and phantasms implied by Dominic's conclusion-phantasia circa phantasmata. Proper and common sensibles are both per se objects of sensation so far as they make an impression upon the senses ${ }^{36}$ (and so it is interesting that the per accidens sensibles seem to occupy a middle ground here concerning a tendency towards error, though Aristotle himself suggests the tendency for deception concerning the common sensibles); ${ }^{37}$ Dominic's conclusion implies that phantasms are related to the phantasia as proper objects. If we are concerned to treat Dominic as a careful reader of Thomas, then we should note that Thomas does not explicitly state that phantasms are the objects (and certainly not the proper objects) of phantasia. That there is room for interpretation within Thomas's own thinking concerning the place of the phantasm is evidenced by Dominic's ambiguity on this very matter; elsewhere in the EDA, he will interpret the 'intelligible matter' proper to mathematical science as materia phantasiabilis. ${ }^{38}$

\section{THE ESTIMATIVE AND COGITATIVE POWER}

That we have concluded our reading of the second tractatus with a consideration of the tendency towards error in the common and contingent sensibles is fitting, since in order to offer a more complete treatment of the interior senses we must turn back to Book II of Dominic's EDA. It has been observed by recent commentators that the cogitativa in Thomas's account of human understanding plays perhaps a more important role-some might say a more convoluted one-than the other internal senses. ${ }^{39}$ We can find Dominic's treatment of

36 Cf. ST Ia , 78, 3, ad. 2, p. 254; Dominic follows Thomas on this point: «differentia sensibilium sumenda est secundum differentiam immutationis. Vel ergo tale sensibile nihil facit ad immutationem sensus, vel aliquid facit. Si primum, sic est sensibile per accidens. Si secundum, sic est sensibile per se, et hoc est dupliciter, vel quia immutatio attenditur quantum ad speciem agentem, sic est sensibile per se proprium, vel quantum ad modum actionis, sic est sensibile per se commune,» EDA II, tr. 2, cap. 7, 73v, cols. 1-2.

37 Elsewhere, Dominic will clarify, however, that a proper sense tends more towards error concerning incidental sensibles: «Similiter visus magis decipitur circa sensibilia communia, quam circa sensibilia propria, minus tamen quam circa sensibilia alterius sensus, et magis decipitur circa sensibilia per accidens,» $Q M$ IV, Q. 7, a. 9 , p. 210 , col. $1 \mathrm{C}$.

38 Cf. EDA, proem., 61r, col. 2: «[...] materia intelligibili, accipiendo ly intelligibile, id est phantasiabile, id est secundum quod Philosophus intellectum phantasiam nominat»; EDA III, tr. 3, cap. 6, 82v, col. 1: «Ad primum dicendum quod licet mathematicalia sint abstracta a materia sensibili tam communi quam individuali, tamen non sunt abstracta a materia intelligibili, id est phantasibili»; see also EDA III, tr. 4, cap. 2, 83v, col. 1: «[...] phantasia potest accipi dupliciter [...]. Alio modo ut se extendit ad intellectum secundum quod materia phantasialis dicitur materia intelligibilis.»

39 On the cogitative power in Aquinas, the only English monograph devoted to this theme that I am aware of is Klubertanz, G. P., The Discursive Power: Sources and Doctrine of the Vis Cogitativa according to St. 
the estimative and cogitative powers in the middle of Book II, in a chapter that posits one conclusion: that the sensible objects are divided appropriately into proper (per se) and incidental or contingent (per accidens) sense-objects. That these internal senses powers appear at this part of the EDA follows Thomas' own treatment in his Commentary. ${ }^{40}$ A sensible object either makes an impression upon the senses, or it does not. The former are per se sensible objects - apt by their very nature to be perceived by sense-which however are further divided on the basis on the difference of their impression, arising on the part of the active sensible species on the one hand, and on the mode of action on the other: a sense-object is per se and proper when it is naturally ordered to be perceived by one sense alone; however a sense-object is per se but common when it is apt to be perceived not by one sense alone, but by many-viz., motion, rest, number, shape, and magnitude.

Apart from these per se sensible objects are the per accidens or incidental sensibles. Dominic draws attention to the following: (1) that the incidental sensibles befall or accompany (accidere) the per se objects of sense-indeed, Dominic tells us that they are so called precisely because of this; and (2) that the incidental objects or sense are immediately perceived by some other potency, by perceiving the per se sense-objects, whether by some other sense, or by the intellect, or by the cogitative or estimative power. ${ }^{41} \mathrm{He}$ offers some typical examples: something sweet being perceived incidentally by sight (as, e.g., white); seeing something in motion but understanding it to be a living thing; seeing something coloured but perceiving it to be Socrates or Plato by way of the cogitative power; and lastly the traditional example taken over from Avicenna, viz., of the sheep seeing a wolf but perceiving it to be an enemy by way of the estimative power. ${ }^{42}$

Dominic's next note of attention considers the more 'controversial' and disputed role attributed to the cogitativa:

It must be considered that the cogitative power pertains to the sensitive power, and is called by another name, the 'particular reason,' since just as the universal reason gathers together universal intentions, so too is the particular reason said to be a collection of particular intentions, or intentions of individuals. This power, which is called the cogitative power in man, is called the estimative power in brute animals, and they differ

Thomas Aquinas, Saint Louis: The Modern Schoolman, 1952; see also Gonzalez, D., La cogitativa segun Santo Tomas, Manila: Universidad de Santo Tomas, 1960. The cogitativa is given careful attention in a number of $20^{\text {th }}$ century thinkers: Rahner, K., Geist in Welt, München: Kösel-Verlag, 1957 [originally published in 1939]); Fabro, C., «Knowledge and Perception in Aristotelic-Thomistic Psychology», New Scholasticism, 12 (1938), pp. 337365, and the extensive study, Percezione e Pensiero, Milano, Vita e Pensiero, 1941; Lonergan, B., Verbum: Word and Idea in Aquinas, Toronto: Toronto University Press, 1997 [originally published as «The Concept of Verbum in the Writings of St. Thomas», in Theological Studies, 7-10 (1946-1949)]. More recently, following a more analytic treatment, see White, A. L., «Why the Cogitative Power?», Proceedings of the American Catholic Philosophical Association, 72 (1998), pp. 213-227; Lisska, A., «A Look at Inner Sense in Aquinas: A Long-Neglected Faculty Psychology», Proceedings of the American Catholic Philosophical Association, 80 (2006), pp. 1-19. For a critical account of the cogitativa in Thomas, see Frede, D., «Aquinas on Phantasia», in D. Perler (ed.), Ancient and Medieval Theories of Intentionality, Leiden: Brill, 2001, pp. 155-184.

40 This content corresponds to: Sent. De Anima, lib. II, cap. XIII, p. 119-122.

41 «Consideratio tertio, quod ad hoc quod aliquid sit sensible per accidens, duae conditiones requiruntur, quarum prima est quod illud accidat sensibili per se. Secunda est quod illud percipiatur immediate ab aliqua alia potentia, percepto sensibili per se, et hoc sit vel ab alio sensu, vel ab intellectu, vel a vi cogitativa, vel a vi estimativa,» EDA II, tr. 2, cap. 7, 73v, col. 2 .

42 On this classic example, see Perler, D., «Why is the Sheep Afraid of the Wolf? Medieval Debates on Animal Passions», in M. Pickavé \& L. Shapiro (eds.), Emotion and Cognitive Life in Medieval and Early Modern Philosophy, Oxford/New York: Oxford University Press, 2012, pp. 32-52. 
in this: that the cogitative power apprehends the individual as it exists in a common nature, and the estimative power apprehends the individual according as it is the end or principle of some action. ${ }^{43}$

This elaboration of the cogitative power here is brief, and appears to share some similarity with Thomas's exposition of this theme in the Summa. ${ }^{44}$ However, it contains an important element taken over from Thomas's exposition in the relevant lectio of his Commentary $4^{45}$-viz., the apprehension of the individual as existing in a common nature (ut existens sub natura communi) by way of the cogitativa. Dominic's discussion here is not as extensive as that of Thomas, nor does he delve into Thomas's insistence that the cogitativa - so far as it seems to play a pivotal role in apprehending anything precisely as 'this' or 'that' (i.e., the cognition of particulars) - has some affinity with the intellect. Thomas also makes this claim in the relevant article in the Summa. ${ }^{46}$ This seventh chapter continues with objections and responses concerning the per se and per accidens sensibles, however it concludes with a final mention of the common sense that is consonant with the arguments we have already seen ahead in Book III.

If we turn again to Dominic's commentary on the Metaphysics, we find again the cogitativa. Earlier we looked at QM I, Q. 3, a. 3, which asked whether all animals possess memory; the entire question, comprised of five articles, treats de ordine cognitionis quantum ad bruta animalia. The question immediately following moves on to man, giving particular attention to the theme of experience, treating de gradibus cognitionis humanae, quantum ad generationem artis et experimenti. The second article thus asks, «utrum in homine tantum sit experimentum, et si sit, utrum vita hominis regatur experimento.» The objections argue variously that experimentum is not particular to man, and is found in brute animals as well. The sed contra employs the authority of Thomas, arguing that experience pertains to the particular reason, and that the particular reason cannot be found in brute animals; to the second part of the question, the sed contra states that, according to Thomas, man's life is governed not by experience but by universal reason. In the corpus, Dominic argues that experience can be taken in two ways: in the first way, properly, as the collection of many particular things retained in the memory; in the second way, improperly, as a kind of habituation towards something to be pursued or avoided. The latter belongs to brute animals, while the former is the experimentum proper to man alone. Dominic is concerned to account for uniquely human experience; such a notion of experience is immediately tied up with the cognition of particulars. But why is this experience typical to man alone? The first argument offered for this is that the collection or comparison of particular things belongs precisely to the cogitative power. Since this capacity belongs only to creatures endowed with reason, such experience cannot belong to brute animals. It does seem that such animals partake in experience, if only a small bit,

43 «Considerantum quarto quod vis cogitativa pertinet ad partem sensitivam, et dicitur alio nomine ratio particularis, quia sicut ratio universalis est collativa intentionum universalem, ita ratio particularis dicitur collativa intentionum particularium, sive individualium, et illa vis quae dicitur cogitative in homine dicitur estimativa in brutis, quae tamen differunt in hoc, quia vis cogitativa apprehendit individuum, ut existens sub natura communi, sed aestimativa apprehendit individuum secundum quod est terminus aut principium alicuius actionis,» EDA II, tr. 2, cap. 7, 73v, col. 2.

44 Cf. ST Ia, 78, 4, c., p. 256.

45 Cf. Sent. De Anima, lib. II, cap. XIII, p. 121-122.

46 «Ad quintum dicendum quod illam eminentiam habet cogitativa et memorativa in homine, non per id quod est proprium sensitivae partis; sed per aliquam affinitatem et propinquitatem ad rationem universalem, secundum quandam refluentiam. Et ideo non sunt aliae vires, sed eadem, perfectiores quam sint in aliis animalibus,»STIa, 78, 4, ad. 5, p. 257. 
since they are able to develop habits with regard to those things to be pursued or avoided, based on many sensations and the memories of those sensations, and this somehow seems to belong to the nature of experience. Dominic adds that man is not simply governed by experience; the argument for this is that something is ruled by that which is essential and principal in it-what is essential (principale) in man is not experience, but rather universal reason. In response to an objection that posits experience to pertain to reason, Dominic answers that reason is indeed twofold: particular and universal. Experience pertains precisely to the particular reason (cogitativa), so while man is governed by universal reason it does not follow that man is governed only by experience. ${ }^{47}$

QM I, Q. 4, a. 3 asks utrum hominum genus vivat arte et rationibus. The treatment here is quite extensive, focusing in particular on Summa theologiae Q. 79 (which touches precisely on the intellectual potencies of the soul, specifically in article 9 and giving special attention to the procedure of ratiocinativum). For our current purposes, we will look at a single notan$d u m$, and isolate our concern to the cogitativa as it appears here. The cogitative power or particular reason is divided against the universal reason (or, intellective reason) so far as it discovers intentions by way of a kind of comparison or collation of particulars. This is consonant with the treatment we have already seen. The exception here is Dominic's brief mention of medici who assign the cogitativa to a determinate organ found in the centre of the brain. ${ }^{48}$ This assignment is taken from Thomas's Summa, which itself is owed to Avicenna. The topic of localization is not particularly important for Thomas, and Dominic seems to follow suitespecially if we consider, for example, the fondness with which Albert often gives to the theme of localization. ${ }^{49}$ This remark in the $Q M$ is a brief instance in which Dominic elaborates upon any localization of the internal sense potencies to a specific organ (or, a part of the brain); certainly, there is no occurrence throughout the EDA. ${ }^{50}$ Thus, Dominic follows Tho-

47 «Respondeo dicendum primo, quod experimentum accipitur dupliciter. Uno modo proprie secundum quod dicit collectionem plurium singularium in memoria retentorum. Alio modo accipitur improprie, pro quadam assuefactione ad aliquid prosequendum, vel fugiendum. Primo ergo modo experimentum, solum convenit hominibus, sed convenit brutis secundo modo. Primum patet: quia collectio plurium singularium pertinet ad vim cogitativam, quae ratio particularis dicitur: sed solum in animali rationali est ratio particularis. Igitur etc. Secundum patet: quia ex multis sensibus, et memoriis, animalia asseuscunt ad aliquid prosequendum, vel fugiendum, quod aliqualiter ad rationem experimenti pertinere videtur. Ideo aliquid experimenti, licet parum, participare videntur. Et per hoc patet responsio ad tria prima argumenta, ante in contrarium adducta. Dicendum secundo, quod vita hominum non regitur experimento. Probatio Doctor. Sanct. unumquodque regitur, per illud, quod est principale in eo: sed experimentum non est principale in homine, sed magis ratio universalis. Relinquitur ergo, quod vita hominis non regitur experimento. [...] AD QUARTUM dicendum, quod duplex est ratio, scilicet particularis, et universalis. Verum est, quod vita hominis regitur ratione universali, arte informata, ut patebit in sequenti articulo, non autem ratione particulari: experimentum autem pertinet ad rationem particularem, et non universalem. Quae autem sit ratio particularis, et quae universalis, patebit in sequentibus.» $Q M$ I, Q. 4, a. 2, p. 25, col. $1 \mathrm{~B}$.

48 «quod ratio dividitur in rationem particularem, et rationem universalem. Ratio particularis est collativa intentionum individualium, ut dicit hic Doctor Sanctus [...]. Et talis ratio vocatur alio nomine, vis cogitativa, in hominibus, quae per quandam collationem, huiusmodi intentiones adinvenit. Cui medici assignant determinatum organum, scilicet mediam partem capitis, ut dicit Doctor Sanctus in prima parte, ubi supra. Sed ratio universalis, quae dicitur ratio intellectiva, est collativa intentionum universalium, et haec dividitur in rationem superiorem, et inferiorem,» $Q M$ I, Q. 4, a. 3, p. 25, col. 2B.

49 E.g., see Albertus Magnus, Opera Omnia, vol. 5: Liber de Anima, Paris, 1890, lib. II, tr. 4, cap. VII, where he offers an account of the ancients in a digression on the interior senses. For a treatment of Albert on this theme, as well as the authority of Albert in $14^{\text {th }}$ century elaborations of the internal senses, cf. Steneck, N. H., «The Problem of the Internal Senses in the Fourteenth Century» (see note 8); see also Steneck, N. H., «Albert the Great on the Classification and Localization of the Internal Senses», Isis, 65 (1974), pp. 193-211.

50 There is, admittedly, one passage in the EDA where Dominic discusses the brain in the context of the sense of smell and its object. He says that the organ of smell ought to be warm and dry, while our brains are pri- 
mas in favouring what we might call an ontological approach to the soul and its powers-over against what can be seen as a physicalist approach typical of Albert and the Arabic traditionso far as problems of localization are not of central importance for him.

\section{V. 'EXPERIMENTUM’ AND KNOWING PARTICULARS}

In order to go in the direction of a conclusion, we will look again to the $Q M$ for a synthetic presentation of the relationship among the four interior senses. It is asked: utrum ex sensu fiat memoria, et ex memoria experimentum. In the corpus of the article, Dominic answers that memory does arise from sensation, and experience from memory. He remarks that the answer to the problem is not answered by Thomas in the relevant lectio of his Metaphysics commentary, but rather is taken up in in lectio 20 of his Posterior Analytics commentary. Thomas does indeed touch upon the theme of experimentum and its relation to sensation and memory in both the Metaphysics and Posterior Analytics commentaries; Dominic's elaboration here however is not immediately grounded in these texts, so far as he offers a comprehensive account of the relation of the exterior senses to the interior ones, and the ordering of their activities. Dominic notes that the claim that memory arises from sensation can be taken in two ways. First, it can be taken as signifying only sequential order, as one might say that noon follows the morning-this no one will doubt, says Dominic, since it is clear that the interior sense follows external sense and understanding follows the interior sense. In another way, it might signify precisely an element of causation, and this is further divided into either a material cause (which cannot be affirmed in the present case) or a kind of efficient cause: if we are to understand the matter at hand, that memory arises from sense is true in this regard since the impressions of the exterior senses are the effective causes of the impressions of the interior sense. $^{51}$

In a third notandum, Dominic claims that sensus can be taken in four ways. On the one hand, sensus can mean: (1) the sensitive potency itself; or (2) the habit of sensation-by these it cannot be said that memory arises from sensation in the sense that sensation causes memory. On the other hand, sensus can be taken to mean: (3) sensitive operation; or (4) sensitive cognition-by these latter meanings it can be said that memory arises from sensation, insofar as the cognition of the internal senses relies upon external sensory cognition. Dominic goes on to give a brief exposition of higher forms of cognition that rely upon internal sensory cognition: the intellectual cognition of logical conclusions depends upon the cognition of premises, and the intellectual cognition of propositions depends upon the cognition of terms - it is the cognition of terms or words that relies upon the cognition of the interior senses. Dominic does not further elaborate on this; however, we should note that a careful reading of ST Ia, Q. 85, a.

marily wet and cold, and further are larger than those of other animals, which accounts for the fact that we have a worse sense of smell than other animals; cf. EDA II, tr. 2, cap. 13, 75v, col. 2. This follows Thomas' own treatment in the relevant lectio; cf. Sent. De Anima, lib. II, cap. XIX, p. 147. This very question is taken up at length in John of Jandun: Ianduno, Quaestiones de Anima, lib. II, Q. 25 (an homo caeteris animalibus peiorem, odoratum habeat), cols. 181-184, which in turn takes a more physicalist approach, making use of Averroes and Albert.

51 «Uno modo, ut dicit ordinem, sicut cum dicitur, quod ex mane fit meridies, et sic nulli est dubium, quod ex sensu exteriori fit sensus interior, et ex sensu interiori fit intellectus, ordine generationis, secus est de ordine perfectionis. Alio modo accipitur, ex secundum quod denotat habitudinem causae. Et hoc dupliciter. Vel causae materialis, et sic non est concedenda praedicta conclusio. Alio modo, ut denotat habitudinem, quodammodo causae efficientis, et sic, si debite intelligatur, est vera: quia immutatio sensus exterioris, est causa effectiva, actualis immutationis sensus interiores,» $Q M$ I, Q. 4, a. 3, p. 27, col. 1C. 
2, ad. 3 may lend support to the role the interior senses might play in the formation and perception of words. Dominic then posits that there are four kinds of cognition in the soul: sensitive, memorative, experiential, and intellective cognition. To sensitive cognition pertains the exterior senses, while memorative and experiential cognition both belong to the interior senses; intellective cognition naturally belongs to understanding. Dominic emphasizes that the latter kinds of cognition each depend upon the lower. ${ }^{52}$

Dominic continues with a final notandum, which presents a comprehensive elaboration and explicit ordering of the internal senses' powers: with respect to the act of cognition, the exterior senses (and most of all sight) precede the common sense, which is ordered for the reception of sensible forms as such; as for the retention or preservation of those sensible forms, phantasia (or the vis imaginativa) is assigned, which follows from the common sense; then the estimative power follows, which is ordered for the receiving and apprehension of intentions not gained through external sensation concerning the agreeable or harmful-again, the cogitativa or particular reason in man; lastly follows the memorative power, which is ordered for the preservation of such species, for this potency is a treasury of these intentions. The power of memory in man, however, extends beyond the capacity of brute animals, since by reminiscence man can search into the memory of the past in a syllogistic manner. Speaking of the order of the sensitive capacities, Dominic restates that the common sense arises from the external sense, phantasia arises from the common sense, the estimative/cogitative from phantasia, and the memory from the cogitative..$^{53}$

The merit of Dominic's elaboration, as we find in his $Q M$, lies in the very conception of a continuous ontological chain or hierarchy among the sensitive powers themselves, and not merely the reliance of the intellective upon the sensitive, and the sensitive upon the vegetative. Dominic seems perceptive to the elevated role that Thomas gives to the cogitativa, however he downplays this in his EDA. A sign of this is that the cogitativa reappears only once in the final two treatises of EDA III: viz., in the treatment of appetite, where the ratio particularis is offered as the principle of locomotion in man. If we grant to Dominic the reliance of the cognition of terms or words upon the interior sense, then this further implies something of a direct line which extends from the intellective realm into the sensitive, or vice versa. Does such a 'direct line' violate those ontological principles which prohibit the sensitive from encroaching upon the intellective? Sense, after all, is cognizant of particulars, and the intellect of universals. Or, is it rather the case that the realm between sense and intellect-a realm which of necessity is phantasmal-remains ever-opaque. Thomas does grant the intellectual cognition of particulars, albeit such cognition is indirect and

52 «[...] sensus accipitur aliquando pro potentia sensitiva, et sic memoria non fit ex sensu, secundum quod, ex importat habitudinem causae. Alio modo pro habitu, et sic simile est iudicium, sicut de potentia. Tertio modo pro operatione sensitiva. Quarto modo pro cognitione sensitiva. Et istis duobus modis, manifestum est ex 1 Posteriorum lectione 20 quod cognitio sensitiva interior, dependet a cognitione sensitivae exteriori, et cognitio intellectiva terminorum, a cognitione sensitiva interiori, et cognitio intellectiva propositionum, a cognitione intellectiva terminorum, et cognitio intellectiva conclusionum, a cognitione intellectiva praemissarum: etiam accipiendo ly, ex secundum quod importat habitudinem causae quodam modo efficientis. Unde quattuor sunt cognitiones animae. Primae est cognitio sensitivae, quae pertinet ad sensus exteriores. Alia est cognitio memorativa. Tertia est experimentalis, et haec duae pertinent ad sensus interiores. Quarta est cognitio intellectiva, quae pertinet ad intellectum. Secunda praesupponit primam. Et tertia secundum. Et quarta tertiam,» QM I, Q. 4, a. 4, p. 27 , col. 1D.

53 «Haec autem vis, in homine addit supra memoriam in brutis, reminiscentiam, tanquam propriam passionem, quasi syllogistice inquirendo praeteritorum memoriam, ut expresse dicit Doctor Sanctus in prima parte, quaestione 78 articulo ultimo. Ex quo patet, quod si illa praeposito, ex dicit ordinem tantum, sic ex sensu exteriori fit sensus communis, ex sensus communi fit phantasia, sive imaginative, et ex phantasia fit estimativa, sive cogitativa, et ex cogitative fit memoria,» $Q M$ I, Q. 4, a. 3, p. 27, col. 2A. 
by way of reflection, in the conversion towards phantasms; in the cognition of singulars the cogitativa does play a prominent role. ${ }^{54}$

The present study has remained confined to the theme of sensible cognition, and thus has not taken up Dominic's treatment of the operations of the intellect. It should be clear, however, that sensible cognition ought not be understood simply as the apprehension of sensible species via the external senses and the perception of material objects; rather, sensible cognitionwhich includes the collaborated work of the inner senses - entails also a conception of interiority that accounts for uniquely human experience. Thus we find that Dominic, in his mature work, posits memorative and experiential cognition alongside sensitive and intellectual cognition. We have shown that Dominic never veers far from the 'Holy Doctor' in his elaboration of the interior sense powers. Regarding Dominic's Expositio in particular, it is clear that it was printed and circulated in the $16^{\text {th }}$ and $17^{\text {th }}$ centuries precisely as a kind of compendium. It does seem that the commentary of John Versoris served as a mediating source, though it is clear that Dominic attributes the correct understanding of the text at hand to Thomas. An avenue of further research might entail a more complete analysis of Versoris and the merit of his commentary. Dominic's treatment is an extraction of the key theses and arguments in Thomas's work concerning the soul and its powers. Thus, we do not find many elaborations in the Expositio which extend very much beyond the text at hand-which is not to say that there are no divergences, as we have tried to show. We have further found that Dominic does employ material from the Summa in his exposition. If we can take our topic at hand as a kind of sample case, however, then we can tentatively conclude that Dominic's great Metaphysics commentary is a locus in which Dominic's own voice is heard more clearly. Employing a complementary test case on a cognate issue would only lend support to this claim; and this certainly stands as a desideratum for further research. It is in his $Q M$ where he weaves together additional works of Thomas in an explicit manner, as well as a variety of other authors, so as to offer a more comprehensive treatment, which lends itself to innovation. Dominic's treatment of the sensitive powers of the soul in his Expositio super libros De Anima, however, serves as a valuable witness as well as window through which we can survey the authority of Thomas Aquinas in the $15^{\text {th }}$ century and a distinctive conception of the soul within the scholastic tradition.

Brian.Garcia@hiw.kuleuven.be

Fecha de recepción: día 15 de diciembre de 2014

Fecha de aceptación: día 9 de septiembre de 2015

54 See e.g., Fabro, C., «La percezione intelligibile dei singolari materiali», Angelicum, 16 (1939), pp. 429462. For Dominic's treatment of the cognition of singulars, see EDA III, tr. 3, cap. 2, 80r-81r. Dominic follows Thomas insofar as he holds that singulars are understood not directly, but rather indirectly and by way of a reflection (singularia possint indirecte et reflexe intelligi). We should note that in this discussion in Book III-which takes up the object of the possible intellect-Dominic does not introduce the cogitativa. 